\title{
3D SURVEY OF THE SAN CARLO THEATRE IN NAPLES
}

\author{
Valeria Cappellini, Massimiliano Campi \\ Urban/Eco, University of Naples Federico II, 80134 via Tarsia 31 Napoli, Italia - (valeria.cappellini, campi)@ unina.it
}

KEY WORDS: 3D modelling, laser scanning, technological integration, digital documentation, graphic representation

\begin{abstract}
:
The article reports the approach developed for the 3D modeling of an important monument in Naples: San Carlo Theatre, the oldest Opera House in Europe recognized as a UNESCO World Heritage site.
\end{abstract}

\section{INTRODUCTION}

The introduction of new measurement techniques such as 3D laser scanner and the application of the newest systems for the photogrammetric reconstruction have caused a considerable change in the operations of capture and processing the metric data.

These useful instruments allow to obtain data with high degree of exactness and accuracy but they need to be properly interpreted by the operator.

As a matter of fact, reality in its complexity needs a series of interpretation models able to put next to metric data the formal and cultural values of an architectural artefact.

The amount of information obtained by new technology determines a loss in the capacity to select picking data. Creating a series of information not always available for specific purposes, these instruments determine models for a knowledge of reality in its complexity rather than in its specificity.

The focus of this work is to test the potential and advantages of laser scanner technology and defining a procedure producing info-graphic representation directed to form an exhaustive data base of San Carlo Theatre.

In particular, the research has been divided into three phases of work:

1) Historical and bibliographic records on the San Carlo Theatre; 2) Metric / material survey with innovative technologies: Lynx Mobile Mapper, laser scanners and photogrammetry; 3) The graphic rendering organized in a systematic database.

This procedural method for architectural modeling allows the creation of a measurable and navigable model that is undoubtedly a huge advantage, not only to document and to monitor an architectural work of great value, but also to preserve its status.

The uniqueness and the extraordinary artistic value of this opera house makes it so important that should be protected and preserved such as monuments of great cultural value.

The preservation and the enhance of cultural and landscape heritage are the prerequisites for the development of civil and social life in each country.

For these reasons the goals of this research are:

1) to study the historical evolution of the theatre San Carlo.

2) to emphasize the characteristics and values of the environment in which the San Carlo Theatre is located to verify the level of interest, the state of preservation, the ability to attract.

3) to survey and document San Carlo Theatre with the modern technologies available today;

4) to create a database of information readily available from a large number of users, not necessarily specialists.

\section{SAN CARLO THEATRE}

\subsection{Brief historical background}

The operations that precede a process of knowledge related to architectural object are referred to a critical understanding of historical, socio-cultural and economic factors.

San Carlo Theatre is the oldest Opera House in Italy: it is 41 years older than La Scala Theatre in Milan and 51 years older than La Fenice Theatre in Venice.

It was built in 1737 by King Charles of Bourbon who wanted to endow his city with a new and great theatre symbolizing the royal power.

It was located near the Royal Palace, in the centre of political, commercial and social life of the Royal Court.

The project of the new theatre was assigned to the spanish architect Giovanni Antonio Medrano, who drew a horseshoeshaped auditorium with six planes of boxes and one Real box in the second plan. It had 2.400 seats, gold and silver decorations and blue upholstery.

The theatre was inaugurated on 4 November 1737, the king's name day, with a performance of Domenico Sarro's Achille in Sciro, an opera based on the play by the famous poet and dramatist Metastasio.

In 1767 Ferdinando Fuga carried out a renewal work of the theatre in the occasion of the marriage of the King Ferdinando IV with Maria Carolina and in 1778 he redrew the auditorium adding eight boxes, four in each side of the proscenium.

In 1809 Gioacchino Murat, nominated king of Naples by Napoleon, assigned the project of the new front, the foyer and pool halls of the theatre to the architect Antonio Niccolini, who became the official architect of the theatre. His most important change in the auditorium was represent by four Corinthian columns, insert between the boxes build by Ferdinando Fuga, which supported the proscenium arch.

On 12 February 1816 the San Carlo was destroyed by fire. However, it was rebuilt by Antonio Niccolini within ten months on order of King Ferdinand IV. 

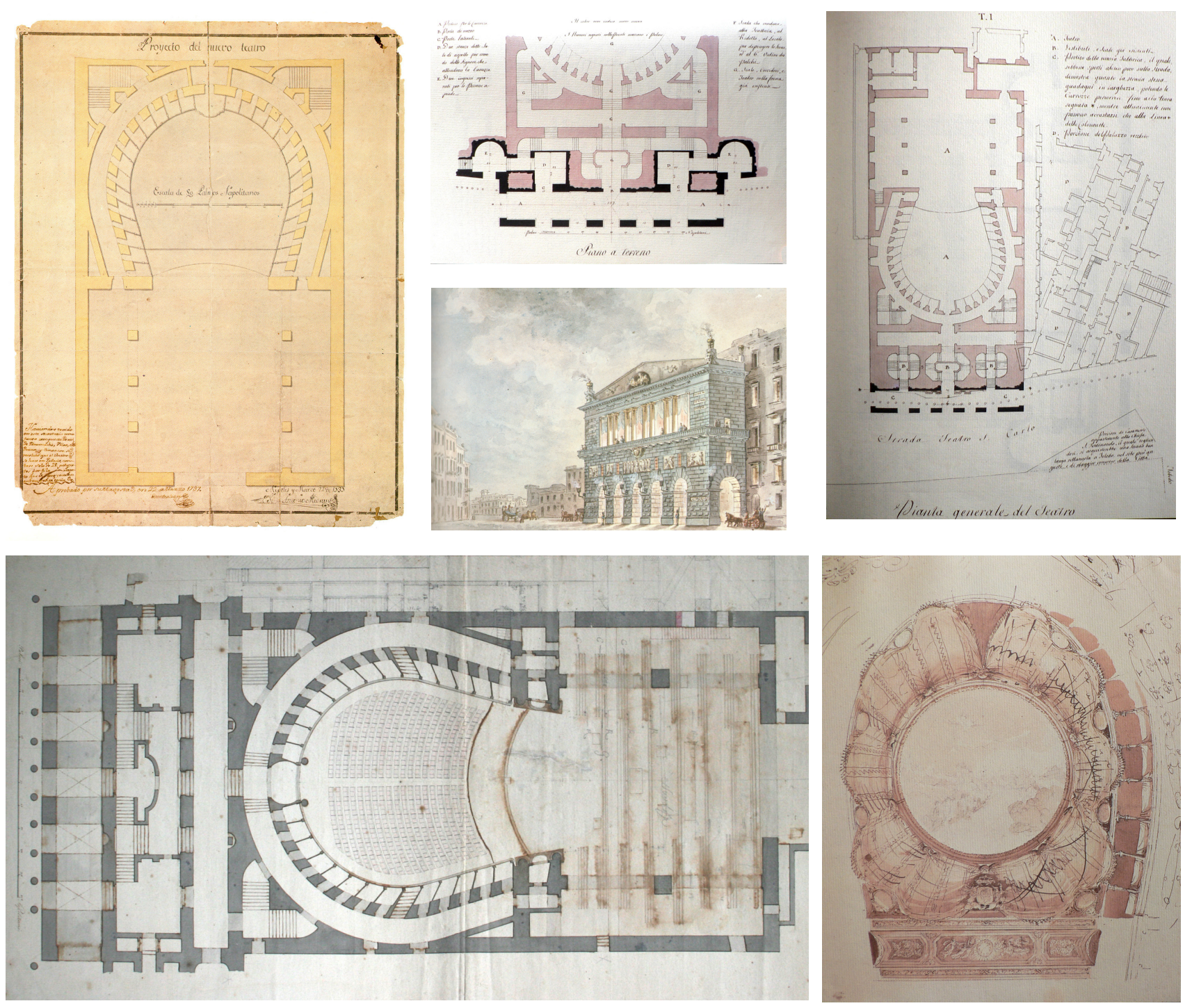

Figure 1 Historical documents of San Carlo Theatre

In the new drawings of the theatre the architect presented again the project of 1809 . In fact he had the possibility to make better the previous planning choises and worked with more awareness and experience.

On 12 January 1817, the rebuilt theatre was inaugurated with Johann Simon Mayr's Il sogno di Partenope.

In 1834 and 1844 there was a new renovation works by Antonio Niccolini, his son Fausto and Francesco Maria del Giudice. The main aspect of the new intervention has been the change of the theatre's interior appearance to the now-traditional red and gold. Also in the 1844 Francesco Gavaudan and Pietro Gesuè built the western front of the theatre.

Apart from the creation of the orchestra pit suggested by Verdi in 1872 , the installation of electricity in 1890 , the subsequent abolition of the central chandelier and the construction of the new foyer and a new wing for dressing rooms, the theatre underwent no substantial changes until the bombing of the Second World War in 1943. However, the theatre was quickly repaired by the occupying Allied forces, and it re-opened within six months on 16 December 1943.

In 2009 the theatre was renovated by the architect Elisabetta Fabbri. It was built a new foyer, the auditorium decorations were restored, it was installed an heating system under the new seat in the stall, replaced to improve the audio-visual system of the auditorium.

This chronology shows that an Opera House is a complex system, whose investigation and knowledge is realized only with an analytical method, based on scientific criteria.

A creation of a digital database is necessary to preserve threedimensional information of cultural heritage of this importance that may be exposed to risks of different nature, such arson, pollution, negligence and so on. 


\subsection{The 3D modeling project}

The survey and 3D modeling of Theatre San Carlo started in November 2007 and the project is regulated by the agreements between San Carlo engineering and design department and URBAN/ECO, University of Naples.

The aims of the research are documenting the theatre conditions and integrating metrics, geometric, historical and cultural data.

There are many books and documents describing the historical evolution of San Carlo Theatre but there isn't an update survey of this opera house.

In fact we discovered some drawings about plans, fronts and one section that are outdated and in some cases not reliable for a complete documentation in the Public Records Office of Superintendence of Naples (BAPSA).

For these reasons the goal of this research is to propose a critical investigation, articulated on several levels of detail and referring to a "excellent" example as the theatre San Carlo, using modern technologies to test: the limitations that still exist at the procedural level in the use of laser scanning equipment; the advantages from the innovation without losing the purpose of the knowledge of a building which is its representation and divulgation.

For these reasons we want to guarantee the scientific quality of data and develop a cultural heritage data base that is accessible in intuitively and expeditiously way by a wide audience, with different levels of reading and knowledge.

\subsection{Sensors and problems of data acquisition}

Evolution of tools and methodologies has inevitably required a different approach in the field of knowledge and documentation of architectural heritage.

In this scenario, the technological innovations promote the technical and scientific research to investigating the characteristics of different instruments and producing an interesting comparison, mainly oriented to study the cultural aspects generated by the informatic revolution.

The choice of appropriate methodology used to perform a survey that captures the values of dimensional, structural, formal and cultural work of architecture is an essential process for proper identification and graphic representation of the object that is analyzed. Of course, the object characteristics and the survey purpose influence and direct the choice of instruments and working procedures.

For the 3D documentation of the theatre we employed:

1. range data of the Theatre San Carlo background acquired with Lynx Mobile Mapper;

2. range data of external fronts of the theatre with TOF sensor;

3. range data of auditorium and Sala dell'Unione (room in the second floor plan of the theatre) with phase modulation sensor;

4. terrestrial images to document decorations and details.

The laser scanning equipment, constantly supported by the traditional methods of survey, allows the volumetric reconstruction of an architectural object and urban environment while the photogrammetric techniques are applied in 3D modeling of architectural details.

The 3D survey of Theatre San Carlo faced several logistical problems.
The main front of San Carlo Theatre is located in a busy and narrow street and the western front is in a square where there is a parking.

We decided to use Lynx for San Carlo background acquisition in the night because is the only time of the day in which there is traffic calming. In fact for a good acquisition it is necessary that the Mobile Mapper survey don't stop its route otherwise the laser continue to acquire data generating oversize files.

Another problem is the bad condition of the street for the calibration of the instruments.

However we have integrated this survey with range data by TOF scanner and topographic and imaging information.

In the auditorium and in Sala dell'Unione we used phase modulation sensor but we had limited working time for data acquisition. For this reason we have only six scans from stall and eleven from Sala dell'Unione.

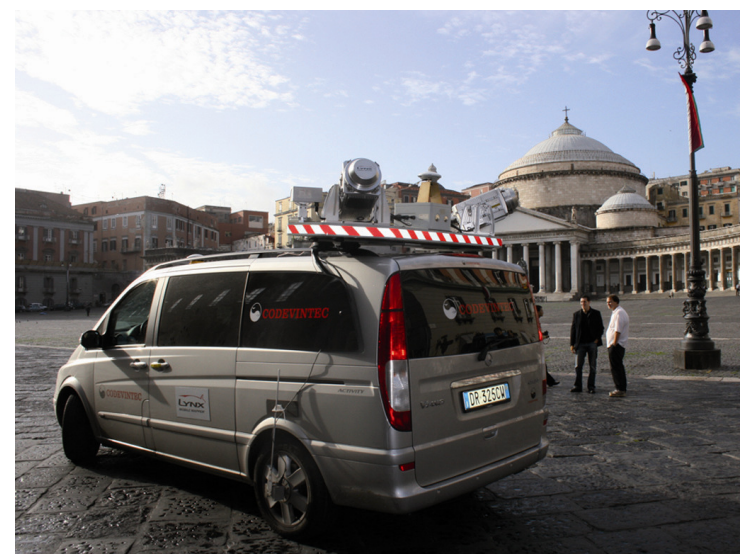

Figure 2. Lynx Mobil Mapper

Lynx is a mobil mapper system formed by four components: the laser sensor, the IMU (inertial measurement unit), two GPS receivers and the DMI (distance measurement instrument, attached to a rear wheel hub measures the velocity of the vehicle). The components are connected to a CPU where data is stored to an internal hard disk and removable SCSI drive.

This survey system can travel at full speed of $100 \mathrm{Kph}$ and acquire 500 points/sq.m. with a geometric resolution of the data spans from $5 \mathrm{~cm}$ to few $\mathrm{mm}$ in geometry.

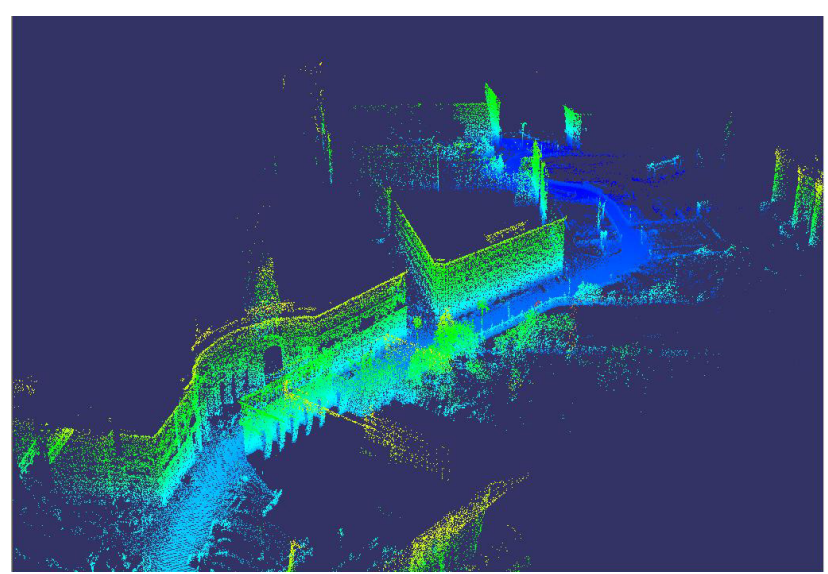

Figure 3 Range map of San Carlo street from Lynx 

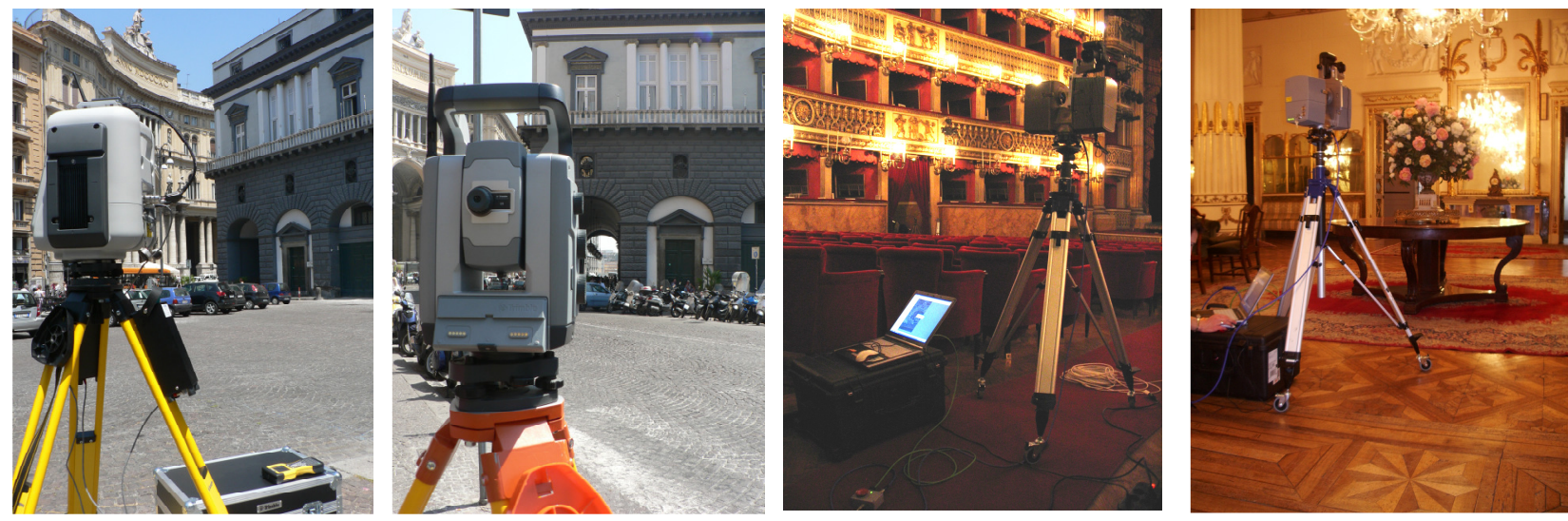

Figure 4 Different instruments employed: GX Trimble, VX Trimble, LS 880 FARO

\begin{tabular}{|c|l|l|c|c|}
\hline & \multicolumn{1}{|c|}{ Sensors } & \multicolumn{1}{|c|}{ Use } & \multicolumn{1}{c|}{ Quantity } & Geometric resolution \\
\hline Lynx Mobil Mapper & Optech (2 sensors) & Background 3D survey & 1 scan (50 Mil pts) & $0.7-50 \mathrm{~mm}$ \\
\hline \multirow{2}{*}{ Range sensors } & GX Trimble & Outer fronts & 10 scans (200 Mil pts) & $6-25 \mathrm{~mm}$ \\
\cline { 2 - 5 } & VX Trimble & Outer frons & 5 scans (25 Mil pts) & - \\
\cline { 2 - 5 } & LS 880 FARO & $\begin{array}{l}\text { Auditorium and Sala } \\
\text { dell'Unione }\end{array}$ & 15 scans (510 Mil pts) & $5-10 \mathrm{~mm}$ \\
\hline Terrestrial images & $\begin{array}{l}\text { Canon EOS 400D } \\
\text { (50mm, 10 Mpixel) }\end{array}$ & Details and decorations & 250 & - \\
\hline
\end{tabular}

Table 1. Characteristics and applications fields of laser scanners employed

\subsection{Data processing}

The range data were processed inside Polyworks (lynx data), JRC 3D Reconstructor (FARO data), RealWorks (Trimble data) and UVACAD (ASCII files).

The scans alignment and data editing required ca 2 months of work by one person.

The application of different instruments have generated files with problems of compatibility. For this reason the modeling task was structurated in several parts. Each part is reconnected in phase of representation.

In this phase of the research we haven't a complete survey of the theatre but the clever combination of various techniques creates an interpretative model in which the information is organized and

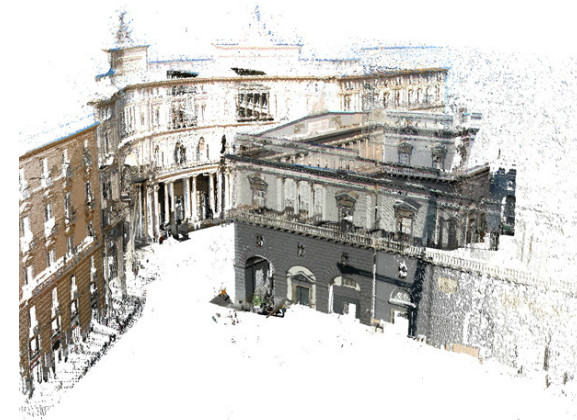

Figure 5 Point cloud of outer fronts, San Carlo street made comprehensible to express and represent the cognitive process. The visualization of data are represented by the conventional "signs" of the architectural design.

In fact we have chosen the combination of descriptive geometry tools with laser scanning and photogrammetric techniques (photographic rectification based on topographic survey) using metrics, geometric, historical and cultural data.

For our research group it is necessary to experiment, using the possibilities offered by technology, the integration of various technical tools to update the our working methods and procedures in the field of the architectural survey.

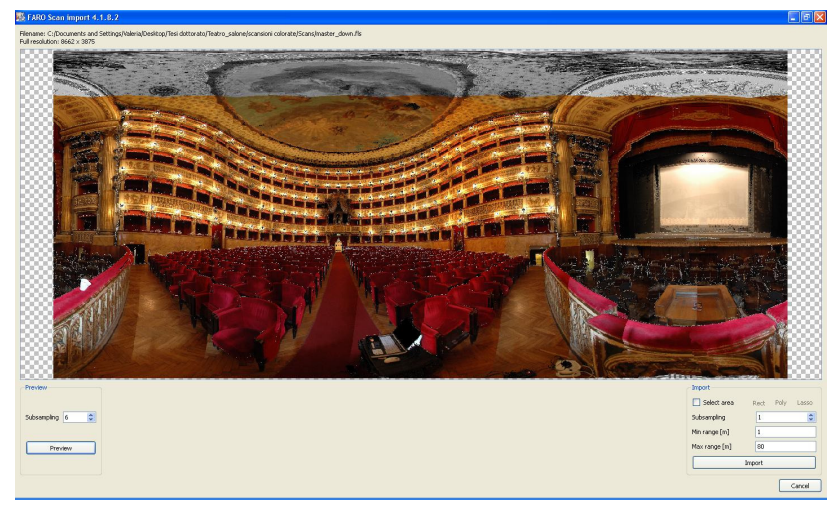

Figure 6 Panoramic view of auditorium (from FaroScout) 


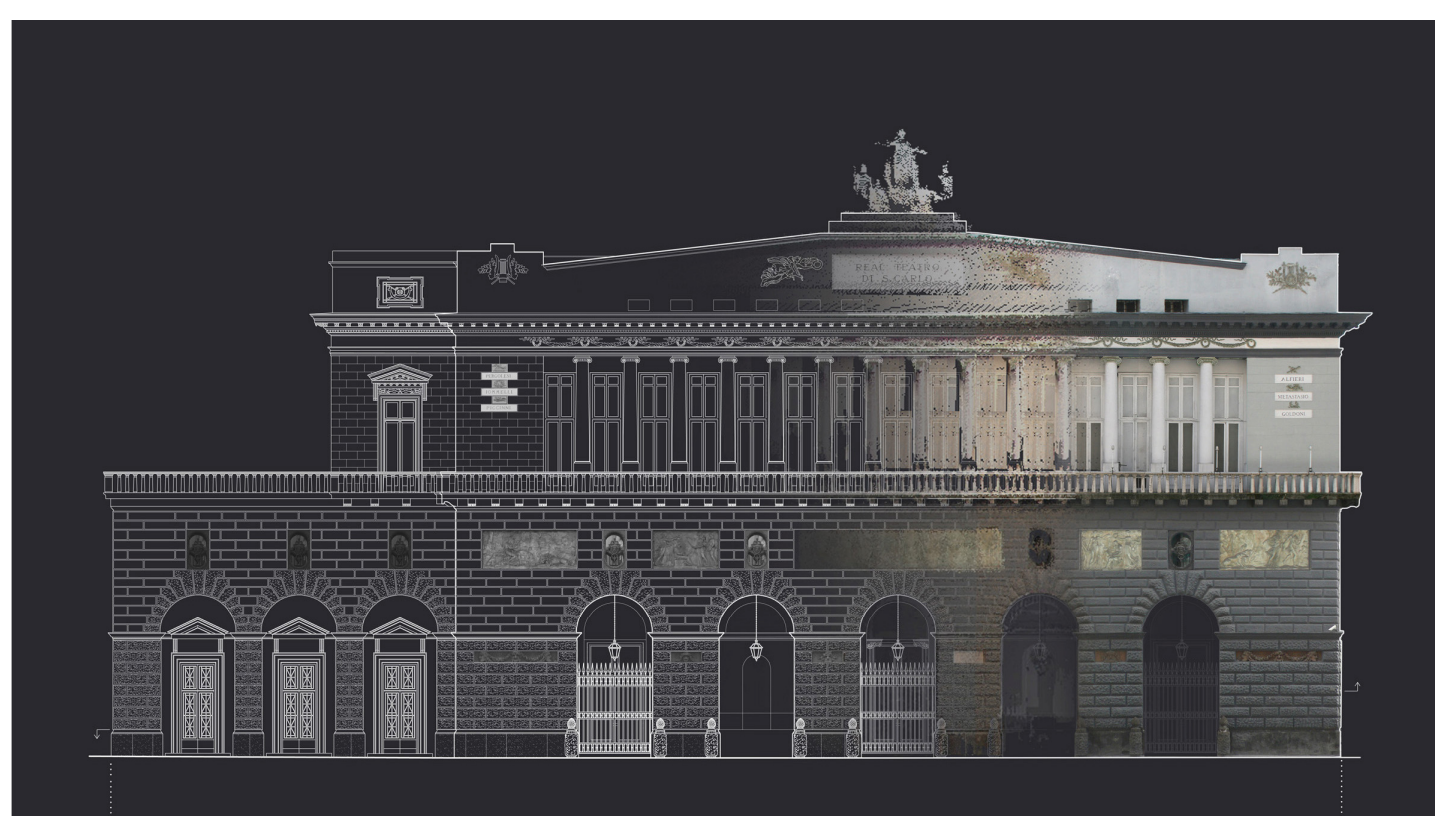

Figure 7 Main front elevation of San Carlo Theatre: integration of the different 3D data

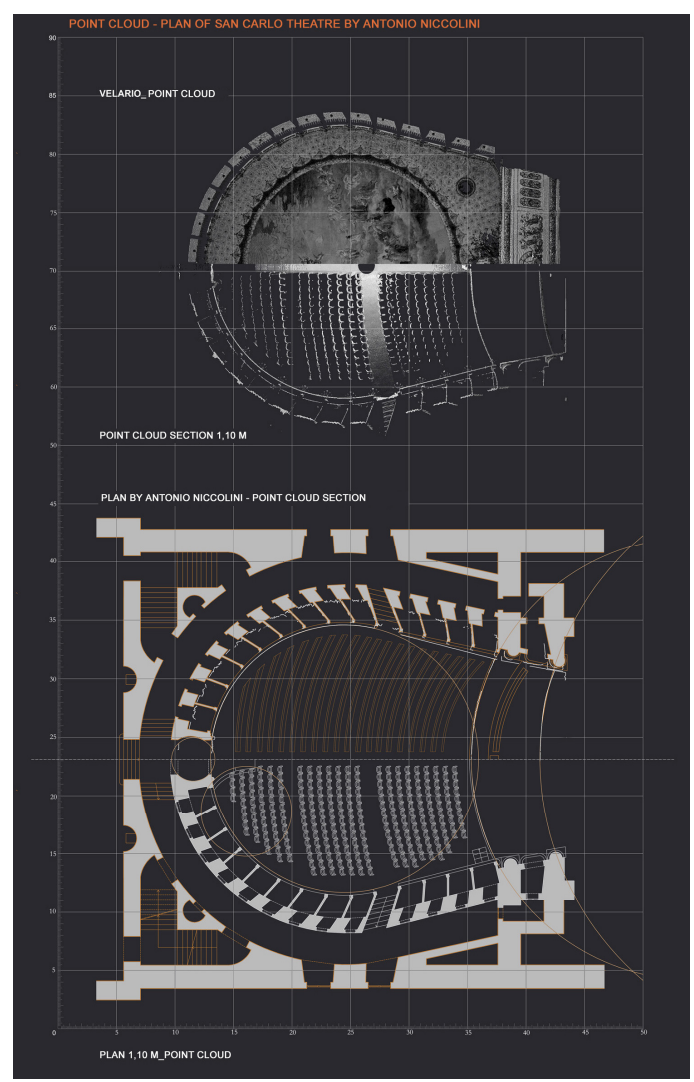

Figure 8 Comparison between the section obtains from point cloud and the plan by the architect Antonio Niccolini

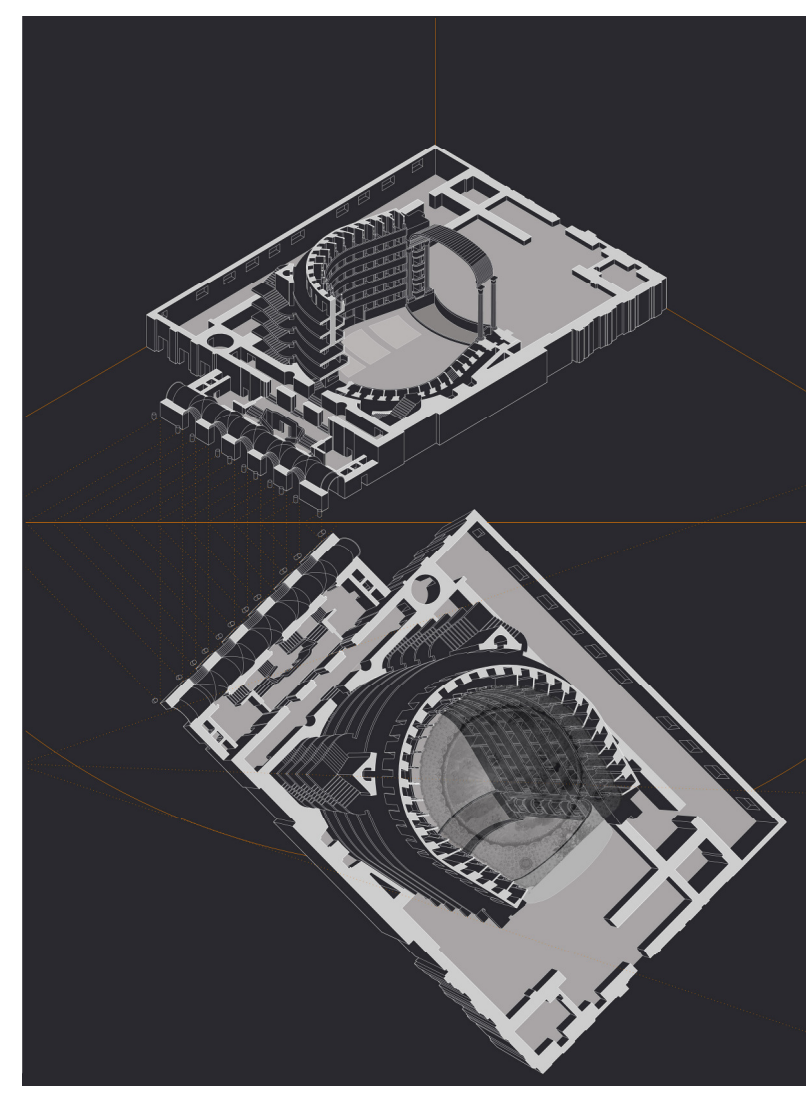

Figure 9 3D visualization of San Carlo Theatre using the traditional graphic methods 


\subsection{The graphic rendering organized in a systematic information database}

Actually the data of the 3D survey allow to obtain useful results for studying and understanding an architectural work, but it is important to translate these pools of data using a graphical language that complete the analysis of the building.

In fact the level of understanding of a work depends on the ability to communicate the elements of iconographical and iconological nature which characterize it, by establishing the relationship between these elements with an interpretive model.

In other words, the organized network of signs that compose an architectural work is ordered according to specific composition rules and only the semantic reading allows to understand, interpret and represent the parties that characterize it.

It is not sufficient to represent the studied object with modern technologies using the images of the point clouds, but also to integrate the 3D survey with the traditional graphical form.

The image of the point cloud is the testimony of a quickly and fast goal, but only the process of the representation of data allows the true knowledge of the object.

Therefore, the study of architectural work is not possible only with its tridimensional model but with its representation understandable by scientist and technicians.

In fact, the focus of this study aims to research the most appropriate form of graphic expression, to communicate the result of the critical information obtained by surveying with laser scanners, and to translate it into understandable visual codes containing the limits of these procedures.

The graphic design must express the different issues approached in the definition of the reality: the knowledge of metrics data, the integration and usability of the information obtained with different acquisition procedures and the interpretation synthesis in which a cognitive model allows multiple readings of interpretation.

The goal is focused on methodological procedures offered by a different use of many technological devices and not only on the technical skills of the machine.

\section{CONCLUSION}

In this paper we have presented the first step of the 3D modeling of San Carlo Theatre.

We have controlled, monitored, documented and analyzed the opera house conditions, creating a information system composed by plans, fronts, sections and 3D model. In fact one of the goals of the research is to create a database available from a large numbers of users, not necessarily specialists in laser scanning or photogrammetry.

The results are satisfactory and encouraging us to complete this operation with other analysis.

The virtual model of the San Carlo Theatre is a new source of documentation which can be used to attest the status of the theatre in the 2007 .

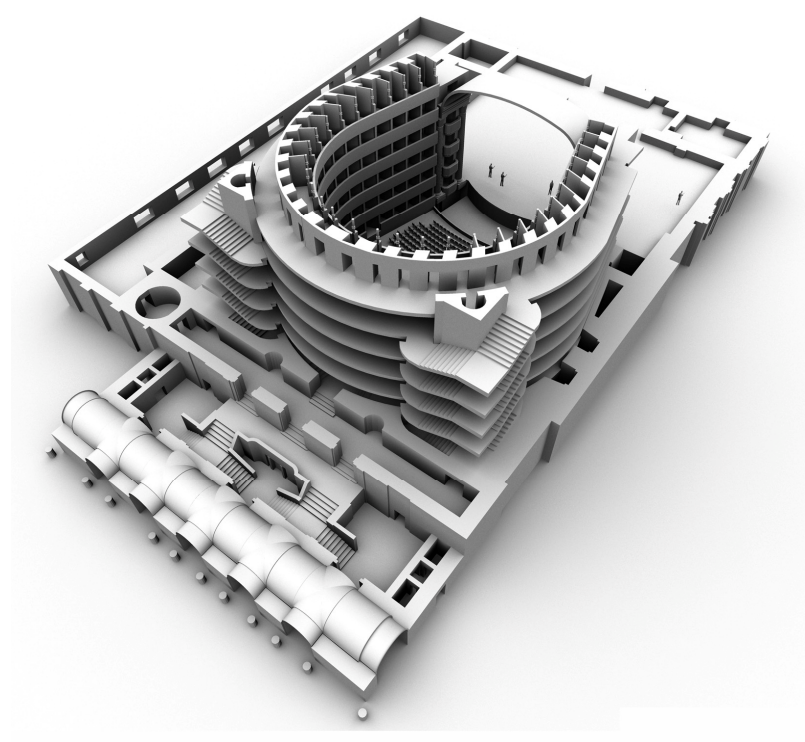

Figure 10-11 3D Modeling of San Carlo Theatre

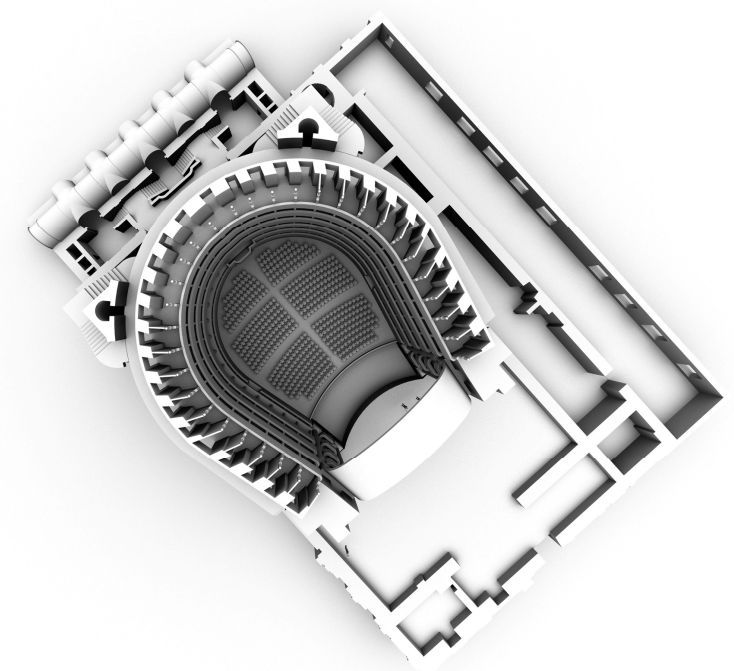




\section{References}

Guidi, G., Russo, M., Beraldin J. A. (2009). Acquisizione 3D e modellazione poligonale, McGraw-Hill.

De Luca, L. (2007). A generic formalism for the semantic modelling and representation of architectural elements, Visual Comput 23: 181-205.

De Luca, L. (2007). Relevé et multi-représentations du patrimoine architectural. Méthodes, formalismes et outils pour l'observation dimensionnée d'édifices, MIAjournal (Informative Modelling for the Architectural heritage) Numéro 1. pages 131-142.

De Luca, L. (2006) Relevé et multi-représentations du patrimoine architectural. Définition d'une approche hybride de reconstruction d'édifices. Thèse de Doctorat de l'ENSAM (Ecole Nationale Supérieure d'Arts et Metiers) d'Aix-en-Provence

Remondino, F., El-Hakim, S. (2006). Image-based 3D Modelling: a Review.Photogrammetric Record, 21 (115), pp. 269-291.

Voltolini, F., Remondino, F., Pontin M., Girardi, S., Rizzi, A., Gonzo, L. (2006) Integrazione di fotogrammetria e laser scanner per la documentazione di beni culturali, Conferenza Progetto ASITA.

Gonzalo, M. (2005) Urban lasermetry. Problems and results for surveying urban historical centres: some pilot cases of spanish Plaza Mayor, Atti del CIPA Symposium, Torino.

Bonora V., Tucci G. (2005), Individuazione degli spigoli su un modello architettonico realizzato da scansioni $3 D$, Atti della $9^{\circ}$ Conferenza Nazionale ASITA, Catania, pp. 15-18

F. Ricca, P. Tonella (a cura di) 2006, Reverse Engineering di sistemi software. Limiti e potenzialità in Mondo digitale, $\mathrm{n}^{\circ} 3$, Settembre.

Sergio Petronilli (2002) Prototipazione rapida, Ingegneria inversa, Beni culturali, Innovare, pag. 29-33

K. Demarsin, D. Vanderstraeten, T. Volodine,D. Roose (2005), Detection of feature lines in a point cloud by combination of first order segmentation and graph theory, Department of Computer Science, K.U.Leuven, Report TW 440, Leuven, Belgium.

C. Chevrier, Y. Maillard, J.P. Perrin, A method for the $3 D$ modelling of historic monuments: the case of a Gothic abbey church, WG V/4 3D-ARCH 09: 3D Virtual Reconstruction and Visualization of Complex Architectures.

K. Demarsin, D. Vanderstraeten, T. Volodine,D. Roose (2006), Detection of closed sharp feature lines in point clouds for reverse engineering applications, Department of Computer Science, K.U.Leuven, Report TW 458, Leuven, Belgium, Mei, 2006.

K. Demarsin, D. Vanderstraeten, T. Volodine,D. Roose, Meshless Estraction of Closed Feature Lines

Using Histogram Thresholding, Computer- Aided Design and Applications 2008.

\section{Bibliography}

De Rubertis, R., (1994) Il disegno dell'architettura, Nis Roma.

Sacchi L., (1994) L'idea di rappresentazione, Kappa, Roma.

Sgrosso A., (1984) II problema della rappresentazione attraverso i tempi, Utet, Napoli.

De Rubertis R., Ermeneusi, in AA.W., Temi e codici del disegno d'architettura, Roma 1992.

Dell'Aquila M., Il luogo della geometria, Arte Tipografica, Napoli, 1999.

Docci M, Migliari R., Scienza della rappresentazione, Roma 1992.

Docci M., Maestri D., Manuale di rilevamento architettonico e urbano, Edizioni Laterza 1994.

Docci M., Migliari R., Scienza della rappresentazione, Roma 1992.

Koenig G. K., Architettura e comunicazione, Libreria Editrice Fiorentina, Firenze 1974.

Panofsky, Erwin, Il significato delle arti visive, Einaudi, Torino 1962.

Purini F., Il Disegno e il Rilievo, in AA. W., Nel disegno, Roma 1992.

Sgrosso A., II problema della rappresentazione attraverso i tempi, Napoli, 1984.

Sgrosso A., La rappresentazione geometrica dell'architettura, UTET 1996.

Baculo Giusti A., (a cura di), Architettura e informatica, Electa Napoli, Napoli 2000.

De Fiore G., Disegnare per conoscere, Il pensiero scientifico, Roma 1960.

Croce B., I teatri di Napoli, Adelphi Edizioni, Milano, 1992.

De Seta C., Mancini F, Isotta P., (a cura di Cesare de Seta) Real Teatro di S. Carlo, F.M.R., Milano, 1987.

Mancini F., Il Teatro di San Carlo 1737-1987, Electa, Napoli, 1987.

Cantone G., Greco F.C., Il Teatro del Re. Il San Carlo da Napoli all'Europa, Edizioni Scientifiche Italiane, Napoli, 1987 